ACTA MUSEI NATIONALIS PRAGAE

Historia litterarum | roč. 64 | 2019 | čís. 1-2 | s. 74-75

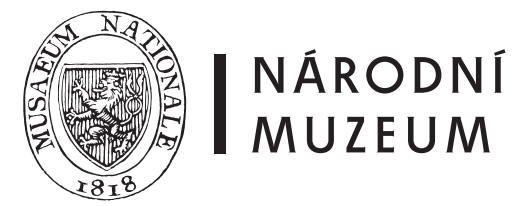

MAREK, Jindřich. Václav Koranda mladší: utrakvistický administrátor a literát. Praha: Nakladatelství Lidové noviny, Národní knihovna České republiky, 2017. ISBN 978-80-7422-586-4, ISBN 978-80-7050-693-6.

\section{Václav Koranda mladší Utrakvistický administrátor a literát}

Jindrich Marek

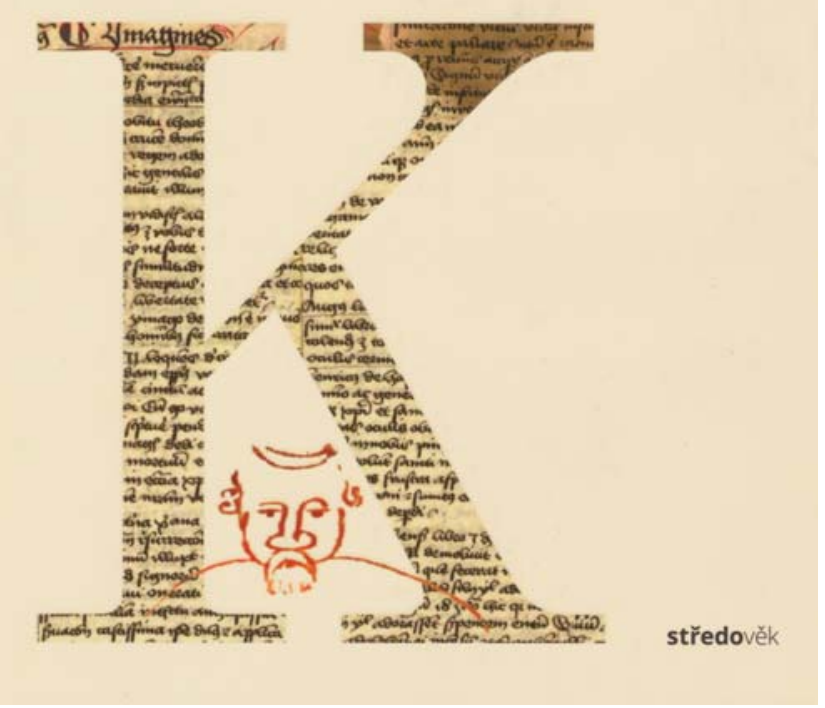

V roce 2016 začalo Nakladatelství Lidové noviny vydávat novou ediční řadu ,Středověk“. Jak název napovídá, je zaměřena na dějiny středověké Evropy a za cíl si klade publikovat především práce, v kterých se uplatňují nové metodologické př́stupy různých medievistických oborů na tradiční, zdánlivě uzavřená témata, přičemž má být kladen důraz na zprístupňování, komentování a výklad středověkých textů. Třetí svazek zmíněné edice, z pera Jindřicha Marka, se věnuje osobě a dílu Václava Korandy mladšího, univerzitního mistra, církevního úředníka a autora mnoha polemických spisů. Po druhém svazku, zabývajícím se zejména činností svérázného tiskaře, autora a editora Mikuláše Konáče z Hodíškova, se jedná o další sondu do českého církevního prostř̌edí, než v něm výrazněji vzbudily ohlas myšlenky německé reformace.

Václav Koranda mladší byl čelným představitelem českého utrakvismu druhé poloviny 15 . a počátku 16 . století, na jehož tehdejším formování - či lépe řečeno vyhraňování - se jako univerzitní mistr, administrátor církve podobojí a autor mnoha náboženských polemik sám výrazně podílel. Jeho osobnost nezůstala v české historiografii nepovšimnuta. Korandovy spisy jsou $z$ větší části vydány a různých aspektů jeho činnosti se dotýká vícero prací. Recenzovaná publikace, k níž si její autor připravil cestu několika dílčími studiemi, na tento zájem navázala a za úkol si vytkla popsat Korandův život a veřejné působení co nejkomplexněji. Kniha přitom není pojata čistě bibliograficky, ale významné pozornosti se v ní dostává i kodikologickému a knihovědnému výzkumu porůznu rozptýlených pozůstatků Korandovy knihovny a rozboru úředních písemností vzešlých z agendy utrakvistické konzistoře během jeho administrátorství.

Na počátku monografie je stručně předestřen její obsah a nastíněny autorovy záměry. Vlastní uvedení do tématu přináší kapitola Písemná kultura poděbradského a jagellonského období. Vedle představení dochovaných pramenů týkajících se Václava Korandy (jedná se hlavně o písemný materiál, který po sobě zanechal) se zde Marek zabývá také různými přistupy ke studiu pozdně středověké knižní kultury a jejími specifiky v prostředí poděbradských a jagellonských Čech. Oproti předchozímu období je známo mnohem více písemných památek, husitství navíc přineslo změny v preferenci žánrů a objevily se i žánry nové. Celkově se do knižní kultury Českého království zřetelně promítlo tehdejší náboženské rozdělení společnosti ovlivňující např. jak skladbu osobních i institucionálních knihoven, tak podobu domácího knihtisku, postupně se prosazujícího vedle rukopisné produkce.

Druhá kapitola Životní dráha Václava Korandy mladšího chronologicky sleduje Korandovy osudy. Poměrně neznámá jsou především léta jeho mládí, o nichž se dochovalo jen nemnoho kusých údajů. V otázce Korandova narození se autor přiklání k roku 1425 . K počátkům Korandovy kariéry s jistou opatrností předkládá tezi, že ji zahájil v úřední službě, nejpravděpodobněji jako písař př́i úradu podkomořího nebo hofrychtéře královských měst. Ohledně diskutovaného Korandova kněžství se kloní k tomu, že zůstal po celý život laikem. Podrobněji je sledováno Korandovo působení na pražské univerzitě, kde studoval již ve 30 . letech 15 . století a kde během 50. let získal bakalářský a mistrovský titul. Na univerzitě poté dál aktivně působil, mimo jiné byl několikrát zvolen děkanem a rektorem, v 50. a 60. letech se podílel na přeměně univerzity v čistě utrakvistickou instituci a díky jeho úsilí se též povedlo stabilizovat její ekonomickou situaci. Jen stručně je v této životopisné kapitole načrtnuta Korandova účast na poselství do Ř́ma roku 1462 a jeho působení v roli administrátora utrakvistického duchovenstva, jimž jsou dále 
věnovány podrobnější výklady. Závěr kapitoly se zabývá Korandovou smrtí a jeho druhým životem, především ve zmínkách, které mu věnovali pozdější literáti.

Třetí kapitola $\boldsymbol{V}$ čele utrakvistické správy si podrobně všímá Korandovy činnosti v rámci konzistoře podobojí, jak byla $\mathrm{v}$ základních obrysech načrtnutá $\mathrm{v}$ předchozí části. V čele konzistoře Koranda aktivně působil v letech 1471 až 1489, než ji musel předat Augustinovi Lucianimu, titulárnímu sankturienskému biskupovi pozvanému utrakvisty do Čech, s nímž se po počáteční bezproblémové spolupráci začal dostávat do sporů. Podstatnou část této kapitoly představuje rozbor agendy utrakvistické konzistoře opřený o unikátní soubor pramenů - pozůstatky jejího archivu ze 70. a 80. let 15 . století, které se dochovaly jako makulatura použitá pro vazbu několika Korandových knih. Část těchto písemností byla známa od konce 19. století, Marek ale jejich počet podstatným způsobem rozšíríl novými nálezy. Celkem tak vycházel z více než 200 zlomků listů a úředních knih spjatých s působením konzistoře, které dokumentují zejména její správní i soudní činnost (mezi řešenými záležitostmi převažují manželské spory a potvrzování kněží $\mathrm{k}$ beneficiím). Jako celek pak materiály svědčí o konsolidaci konzistoře během Korandova administrátorství a po obsahové stránce vykazují návaznost na starší správní postupy obvyklé v katolické církvi.

Dvě následující kapitoly, Polemika s papežem a českými katoliky a Polemika s radikální reformací, představují Václava Korandu jako autora množství polemických spisů týkajících se náboženských otázek. V první jmenované Marek postupně analyzuje Korandovy polemiky a diskuze od jednání $\mathrm{s}$ papežem $\mathrm{v}$ roce 1462 , kdy před ním přednesl žádost o potvrzení kompaktát, přes listy a odpovědi představitelům české katolické církve (Hilariovi Litoměřickému, Joštovi z Rožmberka, Wolfgangu Rabenstainovi a Hanušovi z Kolovrat), odpadlíkům od utrakvismu (Stanislavovi z Velvar, Ondřeji Kulišovi a Janu Markoltovi), blíže neznámému Tobiášovi, papežskému legátovi Marku Barbovi, uherskému králi Matyáši Korvínovi, italskému šlechtici Galeottovi I. Picovi a jeho ženě, Janu Zajícovi z Házmburka až po Traktát o velebné a božské svátosti oltární vydaný roku 1493 tiskem a tzv. Odpovéd' na matrykát bosákuov. Korandův postup proti katolickým oponentům hodnotí autor jako velmi aktivní a poměrně radikální (pokud se nemusel ohlížet na společenské postavení adresáta, často nešetřil ani osobními útoky či urážkami), přičemž argumentační strategie, které si vytvořil, $\mathrm{v}$ průběhu času neměnil. Korandovy spisy namířené proti
Jednotě bratrské a mikulášencům (jedná se o vícero listů adresovaných králi, několika šlechticům, utrakvistickým kněžím či určených pro obecné poučení) pak oproti těm protikatolickým shledává méně vyhrocené.

Poslední kapitola je věnována Korandově knihovně. Dle Marka se ze současného pohledu jedná o jednu z nejvýznamnějších osobních knihoven své doby v Čechách, byt' se z pravděpodobně několikasetsvazkové knihovny dodnes zachovala jen její menší část (celkem 71 knih, z toho 46 rukopisů a 25 prvotisků). Po obsahové stránce ukazuje rozbor vysoké zastoupení teologických děl. Hojné jsou mezi nimi zvláště spisy Johna Wyclifa, Jana Husa a prvních dvou generací českých utrakvistů. Jeho knihy dále odráží zájem o exaktní vědy (astronomii, komputistiku a matematiku), epistolografii a gramatiku. Mimořádně se Koranda zajímal také o historii, i když o tom více než několik v jeho knihovně dochovaných kronik svědčí množství poznámek, kterými ve svých knihách komentoval minulé i současné události. Ostatně, jak Marek dále dokládá, marginálie jsou významným prvkem Korandova čtenářství a jen nemnoho svých knih ponechal zcela bez př́pisků. Pozornost je v této kapitole věnována rovněž Korandově opisovačské činnosti, vztahu ke knihtisku, vazbě knih a srovnání jeho knihovny s dalšími známými knižními sbírkami z této doby.

Velmi užitečnou součástí knihy jsou její obsáhlé přílohy. První je soupis úředních písemností dochovaných jako makulatura v Korandových knihách evidovaných ve formě regestů. Kromě popisu nově nalezených fragmentů přináší i opravy některých záznamů publikovaných již dříve v katalogu rukopisných zlomků Národní knihovny. Druhá př́loha obsahuje stručný přehled dochovaných svazků Korandovy knihovny, třetí ho doplňuje podrobnějšími popisy knih neevidovaných ve starších soupisech. Poslední přílohu tvoří seznam Korandových literárních děl. Starší soupis Pavla Spunara rozšiřuje o několik textů objevených ve vazbách Korandových knih.

Celá publikace prozrazuje pečlivý př́istup a snahu o úplnost, s níž se autor jejího sepsání zhostil. Nejde ale o pouhé shromažd'ování faktů - kniha svým zpracováním přesahuje obvyklé pojetí žánru biografie a představuje vítaný přínos nejen k poznání života jednoho výrazného představitele pokompaktátního utrakvismu, ale i české knižní kultury jeho doby.

Mgr. Zdeněk Mužík 